\title{
ATMOSPHERE IN WORKPLACE MIRROR OF SOCIETY
}

\author{
Kristína KRÁLIKOVÁ, Jozef KRÁLIK
}

\begin{abstract}
The current atmosphere ruling in the society, the quality of created and contemporary relations among people are in principle simultaneously relatively faitfully projected into the relations inside the family, into the collective. Its approximate reflection is present, therefore, in the living working collective. Deformed social relations are deforming, what is clear, also the environment of economic relations. The atmosphere in the working place is immediately influencing the movement of social relations, from the atmosphere unreeled from the state of the society.However, the most dangerous for the society and its existence is the creation of such a situation and the social atmosphere that are directly determined and channeled by non legal and unrightful practices of concret individuals and groups which are typical for the so called social underworld.It is unavoidably necessary also to proceed to the revision of documents concerning the attained education in the interest of the optimal run of the state and its economics that are shoved by managers in all grades and levels of the state and its public administration management. Such a procedure in the private sector should be activated in the facultative base. It would be necessary to eliminate and to remove - on the basis of the exactly achieve results - from management processes and influence such persons that are not shoving the achieved declared education by the trustworthy way. It will be also necessary to analyze their justification and ways of their selection into the management functions together with the determination of the concrete personal responsibility for the contingent unstandard way in the selection process. After the moral and material social damages counting up it will be inevitably necessary to require the compensation from persons and institutions that caused the mentioned damagers. Means accumulated in such a way will be able to use for the development of public estates.
\end{abstract}

Key words:

society, work environment,cadre,education,responsibility

JEL Classification: J81, M54, O35

DOI: https://doi.org/10.52665/ser20210103

\section{Introduction}

Writers are said to be the conscience of the society. Nevertheless the counting that the atmospere existing in the working place is the miracle of the society is also essential. Everything what is taking place in the whole social space , in a great space“ is taking place in the ,small space“, both in the family and in the working place. And the majority of the productive population, not only of the Slovak productive working population, lives in the working collective and spends here the majorityof its active biological and social life (Vojtovič, 2006). Therefore, it could be expected that every individual creative working collective of the certain working place has a natural interest on being the working place confortable. That is why pleasant, peaceful, non conflicted, creative, friendship. At least acceptable. And, of course, oriented the achievement of the most working results not only from the point of view of the employee personally but logically also from the point of view of the whole collective productivity results. All employees,therefore, presenting work succces from the point of view of the whole collective. At the same time it cannot be significant whether the working place is opened or closed, the work is implemented in the narrow or broad, numerous working collective. Or the manual, repective mental work. Everybody who is working should concentrate himself (herself) especially on their work for which they are payed and in the secondary place should be concentrate to other connected circumstances. The manager, on the contrary, must take into the consideration predominanly conditons in which employees managed by him (her) are working.Material, organizational, financially as well as what concerns relations. 
The quality of interpersonal relations is namely the determination factor which parameters have the final influence on employees working results achievement creating the personal substrate of the managed working collective. Therefore to the quality of the final creation of material or mental values. And principially according to the determination of the professional specification respective the concrete working place target orientation. Such a creative atmosphere is typical predominantly for such working places in which employees are considered as the working power and their creative activities have the character of the correctly managed and executed so called dependent work.Regardless the indicated hypothesis defects begin to run in the certain part of working collectives. Also serious. Including those that determine the mutual intolleration of individual employees who could mutually cooperate themselves in their interests as well as their employers ones. It means to "live“ in the atmosphere for the required effectiveness and the productivity of their working place achievement. Unfortunately, such a destructive state of the interpersonal relations in the working place is conditioned not only by the total bad moral state of the society as the whole but predominatly by the noncompetiveness of concrete managers responsible for the „microsocial“" working place situation.

\section{THEORETICAL BACKGROUND}

\section{Dum canis os rodit, socium, quem diligit, odit}

The ancient Roman statement ,as long as the dog bites the bone, he (she) hates even his (her)favourite mate" is valid for a great part of working places located in the public and the private sphere (Rebro, 1986). Members of the working collective selection according to the indicated principle is also a reality today.Therefore, the inadmissible natural or artificial selection of employees in the working place is visible when the employees are rewarded by managers subjectively.Usually inequitable, not objectively according to the quantity and quality of performed work, its strenuousness, complexness but according to another formula. Usually exclusively subjectively determined and implemented by managers. The employees sponging on others de facto „bite the bone“. They take possetion of other colleagues work fruits. They are afraid very easily of „the bone lost“ (it means every the smallest their benefits). They consume the non deserved reward.If other employees demaged by a such situation show on it, they are becomming their non welcomed competitors. Actually a natural enemy.The object of sophisticated intrigues.Verbal or physical attact in extremal case.

Productive employees are getting to the paradoxical position. Because they reveal directly deformed situation of the working place and relations existing in its space for which manager is responsible they are simultaneously becoming personally observed enemy of such a manager that stimulates directly the concrete atmosphere in the working place by his (her) way of behaviour. That is why a person who is unable to manage the collective. The history as well as the everyday practice confirm that unable persons acting in the higher management levels prefer to nominate the unable employee for the lower management level subordinated to the higher managers. Such a person is easily controllable, tractable, subordinated. A person nominated into the management position in such a way does not see and even does not find the cause of him (her) managed working place devastation. In his (her) uncompetency to manage this working place. He (she) is finding it with grudging among those members that he (she) should support and reward actually for their fairly executed creative work , from results acquires benefits also for him (her). However,in his (her) side, their mind, such a stifle atmosphere in the working place usually recalls the feeling of their threat on the other side. From the side of rightfully protesting,nevertheless highly executed employees. He (she) is finding among them the ,internal enemy“. From the position of other,unrightly prefered employees,their servilized manager is assessed usually positively. They accept purpose-built manager position and the way of his(her) chaotic management as the acceptable, it means subjectively optimal, because it enable to "gnawn the bone“. They actually ignore the tension predominated evidently in the working place.They consider it from their own position as rational.They follow really only their egoistic interest and aim. Such a determined "working parasitism" of a part number of a bad managed working colleective is possible to characterize supportly by the 
„sneaked“ statement as „there are not cakes without work".

That is why employees who are profiting unlegitimaly try to use manager's weak working and personal parts at least temporarily and purpose-builtly. Predominantly his (her) selfloaing and to achieve benefits for themselves utilizing the manager strategically untenable position. The „chief opantated“ by them is becomming in their eyes the object of a silent ridicule, hidden content, backstage slanger and telltale to persons in the higher level than their manager. „Pragmatically non working employees" reckon upon naturally also with the change in the management position. As they are usually able to assess the manager of working collective non stabilized position and evaluate his (her) situation realistically. That is why the are immediately ready to continue in the similar way also in the relationship to potentially new manager. However, the tactics of fawning upon, buying the trust,servilism or „sub-subsuing“ valid effectively in the relationship to one manager need not influence the new manager. Of course, if their tactics is disclosed by him ( (her) and when he (she) analyzes the real situation in working and interrelative relations pulsated in a new working place managed by him (her). An predominantly causes of existing tension. However this problem is connected with his (her) spritual equipment. The character, etics, moral, intuition.And, of course, with his (her) really achieved not only declared education.Professional qualification,practical knowledges.

It is possible to say that the prerequisity concerning the fact that only the working collective outstandingly managed by the „complex" personality is able to achieve outstanding working results. The excellent,very good and good manager can simultaneously notice the situation of the working place managed by him (her), the working morale of his (her) employees, their mutual working and personal relations. They are able to select individuals according to their working results, producted values as well as they are possible to reward morally,materially and financially individual employees. The space for the dissociation interpersonal nor the working relations in the working place managed by them is not created. The opposite is the situation of employees and the working place that came to

\section{managers}

hands

defected personally,civilian,moral and social. That is why a person that is not capable even professionally to manage the collective of subordinated people. That time the struggle for the place at the "gnawn the bone" as it is expressed pertinently by the remembered Rome proverb is starting.It is not possible to speak in such a moment about the non existence of the manager authority .

The authority" is the capability of the subject to be able to function on other subjects in such a way that they feel the acknowlegement, respect and simultaneously in the professional sphere towards such subjects and to achieve a position that other subjects not contest it profesionality and qualification. The aim of the such a competence to affect the public can be, for example, the achievement of the concrete level of behaviour in the interest of the required order in the society. The subject authority can be either natural or constitiated.The authority in the interest of the social relatios functioning is usually created, respectively constituted by the relevant institution whereas its way up is the generally obligatory legal standard or its $\mathrm{su}^{\text {" }}$ (Králiková,2020).

Comming from the indicated prerequisite it runs that the degree the concrete state authority achieved in the population eyes achieved in the population and its representation influence immediately the size of leading managers authority achieved in the employees working collectives. And especially functionaries of the state power and public administration bodies. Including the public institutions functioning in the resort of the education,social services, health care,protection of environment,justice and the defence.Specifically in the state police structures. Of course,the life of the society is reflected directly in the life of individual elements and constituencies. That is why also in communities, families and working colectiveness. The bad personal relations of individuals, conditioned in a certain size by the not good state of the society and the interpersonal relations pulsated in its space can not only be but also usually must be reflected in the vital state of working collectives state too.

\section{Fundamentum est iustitiae fides}

Cicero's famous statement "honesty is the basis for justice" may have been true in ancient Rome, where it is spiced (Rebro, 1986). Although the 
history of this ancient empire refutes this statement as a universal principle applied in the everyday life of the Romans, and if this principle was accepted more broadly or completely by the "Roman people", then at first only in the private sphere (Maškin, 1957). In the current social conditions of Slovakia, however, justice seems to be on the very edge of the interest of the power structures controlling the state and thus also of the interest of their representatives. In the everyday life, their inclinations to greatness, self-admiration and godliness, inviolability and uniqueness are manifested. It means, to the socalled papalism, that is, to the feeling of one's own choice and superiority. And even above the law, above the act. There is thus a visible deep deformation of the personal equipment of the "leaders" of the teams. Intoxication by power distorts especially those persons working in public functions, whose personality parameters show a more primitive mental resp. intellectual base and essentially only a fictitious professional qualification. As a result of the parliamentary elections in 2020, uneducated, greedy, selfish, immoral people became involved, even en masse, even with a potential criminal history of their own. The result of such a personnel transformation of the political background of the state is a shift of the social atmosphere to the border of negativism and nihilism. The air spreading in society signals the beginning of its fundamental rebirth. Namely, the changes in the constellation of society passing from "classical" democracy through the bankless liberal democracy with elements of anarchy and open democracy gradually to the so-called authoritarian democracy. Of course, ending in the field of so-called totalitarian democracy. Clearly only a formal "people's government", infected by usurped power and already resembling a "democratic" dictatorship. That is why, in the modern era of the development of the so-called Euro-Atlantic political and legal culture of "democracy" by civil society, it is absolutely unacceptable. More precisely, a pseudo-democracy that does not know the principle of the competition of opinions, rejects the principle of truth, camouflages the principle of legality and distorts the principle of justice. Honesty is no longer considered at all in the highest political circles. Well, and such a "crooked" atmosphere prevailing in society has the same parameters of propagation as fog. The positions of such a "mixed" social atmosphere appear to be creepy, insidious, confusing and opaque political scenes hiding the essence and goals of their machines and senders. Neither accepting nor the reference of the prevailing public opinion. The "opinion mix" confusing and its addressees, but counting on unpredictable consequences and impacts on the Slovak national community.

The roots of the problem of seepage (penetration) of the social atmosphere thus infected into the environment of working communities therefore undoubtedly lie and evidently manifest themselves mainly in the problem of applying the principle of honesty as well as applying the principle of justice in social relations, including industrial relations. If society as a whole, made up of human individuals, feels a marked lack of honesty and justice in global social relations, this shortcoming is certainly directly or indirectly reflected in the environment of work collectives, as honesty at work and fairness in remuneration 3) that are the cornerstones of the working communities stability. The erosion of both mentioned principles testifies not only to the erosion of labour relations between employees or between employers and employees, but in fact to the disintegration of all social relations. On the basis of ignoring the principle of honesty and the principle of justice and thus the created negative image of the structure of employee groups, the pseudo-transparent way of selecting the leaders of work teams also helps considerably. In spite of the so-called selection procedure, which, however, is carried out mainly formally and already "sewn" in advance on behalf of the "victory" of the pre-selected candidate, a number of people who are otherwise unacceptable for the management position appear:

a) do not have the natural personal leadership qualities and competencies necessary to lead a staff;

b) they do not have the character, will and moral preconditions to lead a working team;

c) do not have the qualifications for professional management of the staff; (Kovalev,1967)

d) do not have social, ethical and protocol training that determines the successful management of the staff;

e) do not have the necessary social or professional experience. 
Disqualification of candidates for the position of manager in the absence of such preconditions is obvious in advance. Despite the non-fulfillment of some, even all the required criteria, management positions, especially in public and state institutions, are often occupied and damage is caused to them by ineligible individuals. Publicly referred to as so-called mental peasants. Persons not only professionally, morally, but also humanly selected by a team of employees acceptable. However, even in such personnel cases, especially in the so-called post-socialist states, the political recommendations of political parties, oligarchs, but also other similar entities, which have previously occupied illegally leading positions in the state, predominate. That is why clientelism, nepotism, bossing, ie corruption, control the actions of many individuals and the institutions run by them. We adhere to the publicly perceived opinion of the public that the selection of candidates and officials of state institutions, including business and public benefit, is often undemocratically carried out according to the political template by so-called non-profit organizations from cadres, which they themselves "managed" and "professionally" according to external instructions.

However, the "incomprehensible" actions in the area of "governance" of the state and its institutions are usually quickly exposed to such excerpted and appointed officials of the public. Including entities, some political donors, behind the "selection" of the (ir) responsible manager. Only in this way can the ever-living foreign influences on the administration of the state and the management of its infrastructure, evidently directed against the interests of the Slovak nation and its homeland, be manifested and subsequently revealed in public life. They are therefore unfair and negatively affecting the economic, social and legal status of society. e.g. in the form of the so-called natural monopolies privatization (Nicholsn,2012). In the case of strict implementation of the requirement of honesty and fairness in the interest of the priority of protection of the rights of the state and the Slovak nation placed on candidates, ie candidates for public office in their selection, the principle of justice would probably apply in relation to privatization and property management. Also, if a natural person whose personal qualities are incompatible with the required management potential, do not guarantee management expertise and do not meet the public interest, settle at the head of the employer's staff, the team of such employees will quickly identify the causes and consequences of "appointment" (Vojtovič, 2008). The unprofessionalism, dishonesty, injustice, the lower character and self-love of the leader of the working team are the fastest and easiest to detect by subordinates. Such revelation is a certain beginning of the process of disintegration of the working team (Králik, 2006).

\section{Dum spiro spero}

That is, as this ancient Roman proverb refers, "as long as I breathe, I hope" (Rebro, 1986). In other words, often the working team has nothing left but hope. Hope for change positive. That is why also incapable, resp. primitive and therefore even everything - a capable manager, in a personal moral portfolio whose hyenisme, hypocrisy, malice, insidiousness, selfishness, benevolence, godliness, greed, or in relation to him the oppositely manifesting five-legged persons, time is ripe. That is, it will also be discovered and subsequently convicted and possibly punished. It is clear that a manager who does not have personal moral qualities, personal physical fitness and fitness, personal mental fitness and resilience, personal legal preconditions and personal qualifications must not only not "occupy", but even remain in his position. Moral or even material damage caused by his tolerance by a higher management level is indelibly directly signed under the disintegration of employment relationships in the staff he manages.

Honest, honest, responsible, truthful and justhonest hard-working employees are internally devoured by the current state of such a team. If the superiors do not solve the problems with the obviously incompetent manager, feelings of disappointment, resistance, demotivation, unhappiness, despair appear in their mental state, which can result in hatred towards superiors and servile "silent" co-workers. Stress-activated defiance of disadvantaged to bullied employees often results in personal revenge, revenge against the employer. And even in the form of sabotaging his own personal and joint work. The work results and performance of individuals and, indirectly, of the "quarreled" team of employees 
are generally below average. Such a severely damaged workplace run by a mentally and professionally immature manager does not fulfill its tasks, lags behind in activity and initiative and thus externally in the eyes of the public also dishonors the work of employees of other workplaces integrated into the joint employer's portfolio. It can even seriously damage its know - how, or even completely destroy the good business name, i. e the reputation of the company (Vojtovič, 2013).

A rational solution to such a situation, despite its fragmentation and complexity, becomes a vital necessity for the employer. Not just an economic need! However, if at least at the employer's minimum level, such an in-house workplace still produces (ie at least "breathes"), measures can always be taken that can realistically return it to the previous level of effective production of required work through consistent validation of employment relationships (i. e "hope"). "). In line with the proverb that only "hope dies last." In that case, however, it is necessary to implement radical measures in the personnel or organizational structure of the workplace by its founder.

The founder of a non-functional or insufficiently functioning workplace must examine not only the potential causes and reasons for deficiencies manifested in the structure of its personnel base, but also the suitability of internal organizational construction of the workplace and its systematic integration into the body of an integrated institution, but usually a legal entity of the employer. Both interventions in the workplace organism should be balanced in order to revitalize it. First of all, however, it is necessary to address the "sick head". Of course, the person of the responsible manager, so that the personnel exchange does not replace one person who is incapable of managing the team with another. A simple finding of real qualification parameters of a candidate for a management position can become a problem in this context. Experience has shown that a significant number of people in the work environment are able to prove their education with relevant documents, such as a school-leaving certificate or a diploma attesting to attaining a university degree. Given the originally slow, latent disintegration of the Slovak education system after 1990, which in Slovakia grew dynamically, especially after 2000, into an open disintegration of the qualitative side of education, it is now impossible to rely on documents of such provenance as verifiable constitutive indicators that really tell and correspond to the " educational reality" of the person concerned.

In Slovakia, many holders of various diplomas, certificates and certificates of education were discovered, but they never actually completed any high school or university studies. Thus, they clearly got to the "confirmation" in a so-called punitive way, usually "for a fee", to which the Slovak legislation also partially responded after 2020. Nevertheless, such persons continue to work not only in private and public institutions, in the management positions of state business entities, but also in the structures of state authorities and public administration. It is obvious that such unqualified resp. uneducated persons cannot objectively convey to society what the public expects of them in view of the function they are currently performing. The failure of these people in management positions is therefore natural, but often unresolved, because their superiors shared the same "fate". Thus, the personnel substrate of the vertical hierarchical structure of many institutions has become the subject and subject of the same "career". This statement also applies to higher education institutions. Within their framework, there was also an overpressure of "non-teaching" and "non-publishing", ie purposefully "produced" associate professors and professors, but also academic officials.

Such, even the senior officials of the university, after a thorough in-depth and objective examination of their career and their own personal "equipment", would have to leave their work on the university campus without delay. Of course, if the executives are then produced for the company and from the alma mater environment also distributed by such dubious educational entities operating on the premises of such educational institutions, objectively no significant positive shift in the way the state, its bodies and institutions are managed can be expected. However, it is clear to everyone that in the quality of the functioning of any system in which such individuals settle and take control, non-standard conditions cannot be remedied. Employment relationships and interpersonal relationships in the workplace also belong to such a circle. This confirms the "eternal truth" that the atmosphere in the workplace directly 
depends on the state of society, on the atmosphere affecting the movement of social relations.

However, the most dangerous for society and its existence is the emergence of such a situation and social atmosphere, which is directly determined and directed by illegal and illegitimate practices of certain individuals and groups, so-called oligarchs, so-called non-profit organizations and financial corporations, owning the so-called social underworld. In order to ensure the optimal functioning of the state and especially its economy, it is necessary to proceed to the revision of documents on acquired education, which prove the management staff at all levels and levels of government and its public administration (Krajniak, 2015). In the private sphere, this procedure can be activated on an optional basis. On the basis of such exactly obtained results, it will be necessary to eliminate and remove from management processes and influence those persons who do not prove the acquisition of the declared education in a credible manner. Subsequently, it will be necessary to analyze the justification and the method of their selection for the management position, together with the determination of specific personal responsibility for any nonstandard procedure in the selection procedure. After quantifying the moral and material social damage, it will be necessary to demand compensation from the persons and institutions that caused them. The funds thus obtained can be used for the development of public goods.

Of course, in order to remove tensions and optimize the social climate in the Slovak Republic, which is also reflected in labour relations, it will be necessary to implement many other radical interventions in the development of current socio - political and economic relations. The goal of the brachial power of the state must be, for example, the gray and black economy, but also the way of governing political subjects, the management of the environment of the population or the way of spilling public goods into the private sector (Murín, 2013). However, the success rate of the activities of all social components held in the interest of the population of the state depends directly on the people, especially on their human maturity, political outlook, social maturity, cultural maturity and especially on the education actually achieved.
Achieving these parameters must be constantly hoped for.

\section{THE RESEARCH RESULTS AND DISCUSSION}

How do they feel the atmosphere

What is the whole of society, so are its amounts. It is possible to confirm whether this hypothesis can be refuted by serious scientific research. However, our goal was to find out approximately the state of the atmosphere currently prevailing in Slovak workplaces. This is through a probe into the opinions and experiences of a small, unrepresentative sample of employees. Persons performing the so-called dependent work, but also persons working at workplaces in managerial or managerial positions. Using the pars method used for this (part instead of the whole), we therefore tried to outline only the possible "work" situation of Slovak society. We assume that the depicted attitude of employees to work resp. The interpersonal relationship and their place in the work team, which we obtained through a survey of the "working microworld", can also diagnose the state of the environment of the "Slovak macro world". The collection of answers of 238 respondents to the questions we asked served us. All of them verbally or in the written form, confirmed the acquisition of secondary education. In general, also professional, with and without a high school diploma.

All of them verbally or in writing confirmed the acquisition of the secondary education. Generally, also professional, with and without a high school diploma. In their answers to the survey questions, anonymous respondents from the municipalities of Bernolákovo, Ivanka pri Dunaji and Vel'ký Biel in the district of Senec in the Slovak Republic in September 2020 commented on their work matters. We distributed the questions through a questionnaire. We have formulated them deliberately so that, if possible, they overlap to some extent. Through this "cross-questioning", we tried to eliminate the expected acute one-time spontaneity of the answer, and thus potentially increase the degree of accuracy of the answers to the questions asked. The content of the questionnaire therefore consisted of the following questions: 
1. You rate the working atmosphere at your workplace as
a) excellent
b) very good
c) bad
d) very bad

2. It has the largest share in the created working atmosphere
b) a manager
c) social situation conditions
a) above standard
b) standard
c) sufficient
d) insufficient

a) working environment

d) a team of employees

The employer creates for you working

3. You consider the remuneration of your work to be

a) reasonable and proportionate work demands

b) sufficient and partially corresponding to the work intensity

c) sufficient but partially unsuitable work intensity

d) disproportionate and inconsistent work demands

4. You consider interpersonal relationships in your workplace to be
a) very good
b) good
c) acceptable
d) unacceptable

5. You consider the results of the work of the team in which you work to be
a) very good
b) good
c) acceptable
d) unacceptable

6. You consider your share in the results of your work team as
a) decisive
b) average
c) below average
d) negligible

7. Have you considered changing your workforce and employment
a) daily
b) occasionally
c) often
d) I didn't think

8. You evaluate the leader of your work team as working
a) a man in his place
b) average
c) below average
d) incapable

9. You perceive the human qualities of the leader of your work team as
a) excellent
b) average
c) sufficient
d) insufficient

The resulting answers to the questions asked have a limited informative value. It cannot be generalized and applied to the atmosphere that currently prevailed in workplaces in the Slovak Republic. In particular, some frustration with society, including employers and employees, as determined by the COVID 19 pandemic, needs to be taken into account. These results can help as a starting point for the establishment and direction of further, more extensive and deeper scientific research that would provide a qualified answer to the degree of interaction between the social atmosphere on the one hand and the working atmosphere on the other. Their final classification created on the basis of the answers of 238 respondents $(100 \%)$ has the following structure: root

ad $1.16(7 \%)$ respondents rate the atmosphere at their workplace as excellent, 117 (49\%) respondents as very good, $91(38 \%)$ respondents and $14(6 \%)$ respondents as very bad.

Conclusion: If we add up the number of positive answers to the question, i.e. evaluating the atmosphere in the workplace as excellent and very good, we find that satisfaction with the atmosphere in their workplace is felt by a narrow majority of respondents 133 (56\%). Dissatisfaction with the working atmosphere was expressed by almost half of respondents, i. e a total of $105(44 \%)$. The survey thus suggests a poor state of the working atmosphere for Slovak employers through the answers obtained by the probe through the probe. The task of further, 
representative scientific research will therefore be to confirm or refute this signal sent to society, at the same time to look for and find the causes of this condition. Of course, there must be a subsequent attempt to eliminate disorders of the working atmosphere in a targeted manner, which must be a task for the relevant state authorities.

More than half of the respondents are satisfied with the atmosphere at the workplace.

ad 2. The largest number of respondents stated that $163(68 \%)$ have the largest share in the created working atmosphere. Only $38(16 \%)$ of the respondents consider "other", ie the staff, to be decisive for the quality of the working atmosphere. The impact of the working environment on the working atmosphere is perceived as decisive by 22 respondents $(9 \%)$ and 15 respondents $(7 \%)$ consider the influence of the social situation to be a determining factor on which the state of the working environment atmosphere also depends.

Conclusion: The finding that employees consider the person of the manager as a decisive element in creating a suitable atmosphere in the workplace was to be expected. However, the unexpectedly low number of respondents considers the current social situation to be a determining factor in the atmosphere in the workplace. A relatively small part of respondents sample think that the work environment has a decisive influence on the working atmosphere. Even the team of employees does not perceive a certain smaller part of respondents as a more important tool for shaping their working atmosphere. However, the human factor is considered by most respondents to be crucial in creating a work-friendly climate, whether it is the leader of the work team or its other members. The structure of the collected responses encourages each employer to pay much more attention to the quality of the employees he selects and appoints to management positions.

The human factor, especially the leading employee of the workplace, has the greatest contribution to the quality of the working atmosphere.

ad 3. According to $26(11 \%)$ respondents, their employer creates above-standard working conditions for them. 91 (38\%) respondents have created standard working conditions. 85 (36\%) respondents consider their working conditions to be sufficient. $36(15 \%)$ respondents evaluate their working conditions as insufficient, i.e actually unsatisfactory.

Conclusion: The survey on a selected sample of respondents confirms almost half the acceptance of working conditions of the interviewed employees (117, i.e. 49\%). However, a slightly higher half of the respondents $(121$, i.e. $51 \%)$ are not satisfied with their working conditions. Of course, we cannot estimate exactly what the respondents imagined under their working conditions. This implies the obligation of the state to take a more consistent interest in the working conditions of all employees and at the same time to put pressure on employers in order to improve them.

Approximately one half of the employees surveyed consider their working conditions to be either acceptable and about half as equal to be unacceptable.

s

ad 4. Among the remarkable results of the survey can be included the structure of answers to the question, subjectively evaluating the remuneration of their own work by the addressed respondents. As many as 92 (39\%) respondents considered their remuneration to be adequate and corresponding to the work intensity, and 76 (32\%) respondents considered their remuneration sufficient and partially corresponding to the work intensity. This means that up to 168 (71\%) employees are completely satisfied or relatively satisfied with the remuneration of their work. If we add to this heading more or less with the remuneration of satisfied respondents who consider their remuneration to be sufficient, but partially unsuitable for work intensity $13(5 \%)$, we get the value of satisfaction with remuneration for work with a total of $181(76 \%)$. It follows that from the examined sample of respondents, he considers his remuneration to be disproportionate and inconsistent with the work intensity $57(24 \%)$. This would encourage the opinion that employees in Slovakia are satisfied with their income from work and would thus question the travel of Slovaks for work abroad.

Conclusion: Given the media and media knowledge gained through uncontrolled 
interviews about the degree of employee satisfaction with the remuneration of their work, the structure of respondents' answers can be considered surprising. They refute their widely held view of the "bad" remuneration of the work of persons employed by employers in the Slovak Republic. Only less than a quarter of respondents do not feel that they are adequately remunerated by their employers for their work.

Most respondents are (relatively) satisfied with the remuneration for the work performed

ad $5.19(8 \%)$ respondents consider interpersonal relations in their workplace to be very good and $24(10 \%)$ respondents to be good. $108(45 \%)$; respondents consider interpersonal relationships in the workplace to be acceptable. Unfortunately, this type of social relationship in the workplace is perceived as unacceptable by up to $87(37 \%)$ respondents.

Conclusion: Only a small part, i.e. 43 $(18 \%)$ of respondents are completely satisfied with interpersonal relationships in their workplace. In fact, respondents relatively satisfied with interpersonal relationships in their workplace form the largest group, reaching almost half in number. The term "satisfaction" with co-workers could therefore be theoretically assigned to a set of 151 (63\%) respondents. However, more than a third of the respondents consider interpersonal relationships in their workplace to be unacceptable, i.e. extremely bad. It would therefore be appropriate for employers to address workplace issues on a regular basis, not superficially. And at the same time to solve emerging problems between employees immediately, in a timely manner, including through appropriate personnel and organizational measures.

Most respondents are (relatively) satisfied with the level of interpersonal relationships in the workplace.

f pro

ad 6. You consider the results of the team work in which respondents behave very good 23 $(10 \%)$ and $56(24 \%)$ respondents good. 127 (53\%) of them feel acceptable and $32(13 \%)$ consider them unacceptable.

Conclusion: Based on the sum of answers, in which respondents expressed relative satisfaction with the results of the staff work of which they are members; it can be stated that the workplaces perform the assigned work tasks of high quality, as such a view is inclined to respondents.

The majority, i.e. $2 / 3$ of respondents, consider results of the staff work in which they work to be acceptable to the employer. of seepage (penetration) of

ad $7.16(7 \%)$ respondents consider their own share in the results of the working team to be decisive. $213(89 \%)$ respondents consider the average own contribution to the work results of the work team, which is the majority. Only 7 $(3 \%)$ respondents think that their work initiative is below average and $2(1 \%)$ consider their work performance in the team to be negligible.

Conclusion: Almost all respondents (229, i.e. 97\%) evaluate their own personal work initiative as an indisputable contribution to having a significant share in the achieved results of the entire work team. Only 9 respondents (4\%) consider their share of work in the result achieved by their work team to be non-standard (below average or negligible). This means that the employer would need to develop a rationally conceived initiative that would purposefully integrate and effectively involve the remaining employees in achieving the maximum possible work performance.

The vast majority of employees are aware of their own share in the results achieved by the work team of which they are a part. i

ad 8 . We received interesting answers to the asked question, through which the task was to find out whether the respondent was considering a change of work team and employment (employer). Every day, 9 (4\%) respondents and occasionally 213 respondents $(89 \%)$ consider changing jobs. The answer "often" was not marked by $0(0 \%)$ of the respondents and 16 (7\%) respondents never considered a change of job.

Conclusion: Despite the indicative results, which we formulated on the basis of previous respondents answers, expressing relative satisfaction with their position in the workplace, up to 222 (93\%) of them are considering a change of work team and employer. Only a negligible part of employees 
did not think about changing their workplace at all. However, the relatively paradoxical results of the opinion poll on this issue need to be confronted with the structure of the answers obtained in relation to questions 1,3 and 5 .

The vast majority of interviewed employees consider the change of work team and employer (employment) in number.

ad 9. $39(16 \%)$ of the respondents and the average of $101(43 \%)$ evaluate the leader of their work team as a person in their place. However, what concerns a person with below-average management skills, $62 \quad(26 \%)$ respondents evaluate their superior and even 36 (15\%) respondents consider their own manager working in a managerial position to be unable to manage the work team.

Conclusion: The majority of respondents consider 140 people, i.e. $59 \%$, to be a person qualified and therefore also entitled to manage the staff of their workplace. Nevertheless, significantly more than a third of the respondents are of the opinion that their superior head of the workplace is not able to manage the workplace at all or that this workplace is managed by a below-average competent manager. The mentioned facts implies the need to re-evaluate the selection procedures and regularly pay attention to the inspections of managers in terms of personal, qualification and practical ability to lead the entrusted staff (e. g administrative skills).

An extraordinarily large number of respondents assess a self-employed employee as having below-average professional qualities, including the ability to lead a team.

ad $10.12(5 \%)$ of respondents perceive the human qualities of their team leader as excellent. $131(55 \%)$ respondents consider their superior to be a human average person. Their leader seems to be humanly sufficient to his subordinates with the number of answers 89 (37\%). $6 \quad(3 \%)$ employees consider their manager to be insufficiently endowed with human qualities.

Conclusion: Basically, it is possible to agree with the opinion that human resp. human characteristics, although dosed in a differentiated way, are part of the vast majority of senior work teams, which include a sample of activated respondents.
Most managers are considered by their subordinates to be human resp. humanly acceptable persons, even if their personal characteristics are predominantly average.

\section{CONCLUSION}

The stability of a community, and often the life of a person, frequently depends on the co-worker or on the attitude of the manager towards the subordinate. That is why great emphasis is placed on managers and especially on their activities in social relations. However, the importance of a minister, director or other manager in a company position and of his work acceptance often completely contests his (not always surprising) personal failure. Professional, social, human. Most often it is his moral downfall. Outwardly, the most pronounced by his willingness to enter into the tangle of corrupt relationships. And even at his workplace. However, it is the compulsivity to submit urge to get rich illegally at the expense of others. Unfortunately, it often happens that only the manifestation of such personal misery is actually the only personal contribution of the manager to the story not only of his own life, but also to the life destinies of others controlled by him. A bitter contribution to the working (non) culture.

Thus, the entire apparatus of the enterprise, the institution, and in many cases the state, its bodies and institutions, dehonestets. Believe me, it can be so sad to see the spiritual emptiness of some people dressed in the "director's coat" of a manager. Despite their illegally built material prosperity, and even undisguised wealth and pride, in the recent period one can also feel significant public pressure in the Slovak Republic on state authorities to radically punish so-called rich people from crime. Despite their arrogance and inaccessibility, the disobedience and ignorance that have so far led the actions of some oligarchic individuals in life, even the "modest" part of society acknowledges the modest results of law enforcement agencies. Steps leading to their detection and punishment. Therefore, even when evaluating each person's working life, society must no longer look at what has been said, but at what has been done.

Taking the above mentioned facts into the consideration, it is clear that the atmosphere 
prevailing in society is reflected in both interpersonal relationships and labour relations. Also our survey resp. the probe into the opinion orientation of a small, ie unrepresentative sample of respondents, clearly, albeit only indicatively, points to the fact that:

More than one half of interviewed persons are satisfied with the atmosphere in their workplace.

1. The human factor, in particular the manager of the workplace, has the greatest share in the quality of the working atmosphere.

2 About half of the employees interviewed consider their working conditions to be either acceptable and about half of them to be unacceptable.

3. More than half of the respondents are satisfied with the atmosphere at the workplace.

4. Most respondents are (relatively) satisfied with the remuneration for the work performed.

\section{References}

KOVALEV, A.G. 1967: Psychológia osobnosti. 1. vyd. Bratislava : Slovenské pedagogické nakladatel'stvo, 1967, $328 \mathrm{~s}$. Bez ISBN.

KRAJNIAK, I. M. 2015: Banda zlodejov. Šokujúca pravda o oligarchoch a politikoch na Slovensku. 1. vyd. Bratislava: Kniha do ucha, s.r.o., 2015, 187 s. ISBN $978-80-$ $972126-0-5$.

KRÁLIK, J. 2007: Verejná správa a možný problém jej financovania. In: Stretnutie finančných právnikov. Zborník Z medzinárodnej vedeckej konferencie Financovanie verejnej správy (aktuálne problémy) konanej 12. a 13. apríla 2007, Liptovský Ján. 1. vyd. Bratislava : Akadémia Policajného zboru, 2007, s. 101 - 108. ISBN 978 - $80-8054-410-2$.

KRÁLIK, J. 2006: Poznámka k aktuálnemu problému fungovania slovenskej štátnej polície a $\mathrm{k}$ súčasnému stavu fenoménu korupcie. In: Sborník. Aktuální problémy veřejné správy ve středoevropských zemích sdružených v Evropské unii (s akcentem na
5. The majority of respondents are (relatively) satisfied with the level of interpersonal relationships in the workplace.

6. Most respondents consider the results of the work of the staff in which they work to be acceptable to the employer.

7. The vast majority of employees are aware of their own share of the results achieved by the work team of which they are a part.

8. The change of the work team and the employer (employment) is considered by the vast majority of the interviewed employees.

9. An exceptionally large number of respondents assess a self-employed employee as having below-average professional qualities, including the ability to lead a team.

10. Most managers are considered by their subordinates to be human or. humanly acceptable persons, even if their personal characteristics are predominantly average.

The collected answers certainly encode the essence of the prevailing public opinion on the current Slovak society quality of life.

problémy korupce). II. Mezinárodní virtuální vědecká konference 2006. 1. vyd. Kunovice : Evropský polytechnický institut, 2006, s. 31- 39. ISBN $80-7314-106-\mathrm{X}$.

KRÁLIKOVÁ, K. 2020: Odborné stráže životného prostredia. (príručka pre bezproblémový pobyt človeka $\mathrm{v}$ slovenskej prírode). 1. vyd. Sládkovičovo : Vysoká škola Danubius, 2020, 102 s. ISBN 978 - 80 $-8167-074-9$.

MAŠKIN, N. A. 1957: Dějiny starověkého Ríma. 2. vyd. Praha : Státní nakladatelství politické literatury, 1957, $736 \mathrm{~s}$. Bez ISBN.

MURÍN, G. 2013: Mafiáni. Krvavé príbehy zúčtovanie? 1. vyd. Bratislava: Marenčin PT, 2013, 293 s. ISBN 978 - 80 - 8114-306-9.

NICHOLSON, T. 2012: Gorila. 1. vyd. Bratislava : Dixit, 2012, 149 s. ISBN 978 $80-971039-1-0$.

REBRO, K. 1986 : Latinské právnické výrazy a výroky. 2. vyd. Bratislava : Obzor, 1986, 272 Bez ISBN. 
VOJTOVIČ, S. 2006: Personálny manažment (Historické súvislosti vzniku a rozvoja). 1. vyd. Bratislava: IRIS, 2006, 288 s. ISBN 80 $-89018-98-\mathrm{X}$.

VOJTOVIČ, S. a kol. 2008: Riadenie personálnych činností v organizácii. 1. vyd.

\section{Contact}

Lt Col. Assoc. Prof. PhDr. Ing. Bc. Kristína

Králiková, PhD., MBA

Academy of the Police Force in Bratislava

Department of Administrative Law Sklabinská

ul. č. 1

83517 Bratislava - Rača

Slovakia

e-mail: kristina.kralikova@minv.sk
Bratislava: IRIS, 2008, 393 s. ISBN 978 - 80 $-89256-17-4$.

VOJTOVIČ, S. a kol. 2013: Personálny manažment v organizácii. 1. vyd. Plzeň: Aleš Čeněk, 2013, 355 s. ISBN 978 - 80 - 7380 $483-1$.

prof. JUDr. Jozef Králik, CSc., MBA

Danubius University

Faculty of Law Janko Jesenský

Richterova 1171/66

92521 Sládkovičovo

Slovakia

e-mail:prof.kralik@gmail.com 